\title{
MALACOFAUNA OF THE FORUM ROMANUM AND ADJACENT ANCIENT ROMAN MONUMENTS
}

\author{
STEFAN WitOLD ALEXANDROWICZ
}

Polish Academy of Arts and Sciences, Sławkowska 17, 31-016 Kraków, Poland (e-mail: sz.alex@vp.pl)

ABSTRACT: Land snail assemblages found among the most famous and popular historical monuments of ancient Rome are the subject of this study. Malacocoenoses found beneath walls of ruins in antique places, among grass and other short vegetation, in places visited by thousands of tourists, are usually ignored by naturalists and thus are only rarely examined. They develop in specific habitats, being under constant and strong human impact. The living fauna is accompanied by thanacocoenoses composed of numerous shells. Species associated with open or even xerothermic habitats as well as mesophile ones, accepting both sunny and shaded habitats, are the main components of these assemblages.

KEY WORDS: mollusc assemblages, ancient monuments, Rome, Italy

\section{INTRODUCTION}

Castle ruins and other historical monuments, rarely visited by tourists and situated outside towns, among more or less wooded mountains, foothills, highlands or in the lowlands of the temperate climate, offer relatively favourable ecological conditions for associations of specific plants and animals. The diversity of habitats and the substratum, enriched with calcium carbonate which originates from disintegrating and weathering walls of old buildings, are typical features of such objects, particularly preferred by numerous species of land snails. Relatively rich mollusc assemblages have been described from ruins of twenty old castles in the Polish Carpathians (ALEXANDROWICZ 1995) as well as from a few similar sites in Germany (ZEISSLER 1968, 1980, MÜNZIG 1977, MATZKE 1985, HALDEMANN 1990).

On the other hand, ancient monuments situated in countries of the Mediterranean climate, especially within popular tourist centres, offer unfavourable ecological conditions. Their less diverse biocoenoses, usually ignored by naturalists, are rarely examined and therefore remain only poorly known. One of the most popular Italian monuments - the Roman Forum (Forum Romanum) in Rome, visited yearly by thousands of tourists, provides a good example. Patches of grass and other short vegetation are distributed there among ruins and old buildings, forming habitats which remain under strong human impact. They are inhabited by a relatively poor and moderately diverse malacocoenosis; the thanatocoenosis derived from it is composed of numerous shells. Similar assemblages of land snails were also found within a few other ancient monuments of Italy. The results of investigations presented here are the fourth contribution to the joint scientific project of the Polish Academy of Arts and Sciences and the University La Sapienza in Rome (ALEXANDROWICZ 2003, 2004, 2005).

Forum, the adjacent Palatine Hill and Capitol Hill, as well as the neighbouring Colosseum. The Forum was chosen as the main and most important object. It is ber of 2001, 2003 and 2004 within four ancient monuments of the Italian capital. These were the Roman

\section{STUDY AREA AND METHODS}

Field work was carried out in October and Novem- 
the oldest urban square of the antique Rome, where a few temples, basilicas, triumphal arches and columns were built in the times of the empire. In the Middle Ages a considerable part of these buildings was destroyed, while archaeological excavations and conservation of the ruins continued regularly since the end of the 19th c. At present the surface of the Forum square between the remains of buildings and pavements is partly covered with grass and other short vegetation which develops on the sandy soil enriched with much fine calcareous rubble. The fauna of small land snails, and the associated thanatocoenosis were sampled from this substratum and from beneath the walls.

The Palatine Hill rises about $40 \mathrm{~m}$ above the south-eastern part of the Forum. Ruins of temples and of imperial houses from the empire period are situated there within the area arranged as a park and covered by short vegetation composed of grass and other plants, as well as shrubs and trees. The Capitol Hill crowned by the Senatorial Palace (Palazzo Senatorio) and the Restoration Palace (Palazzo dei Conservatori) flanks the Forum on the opposite side. In the western part, close to the Rampa di Cafarelli, it is also overgrown like the Palatine Hill, while in the south-eastern part, above the Via del Consolatione street, open habitats prevail.

Malacocoenoses and thanatocoenoses were also found inside the major ancient attraction of Rome Colosseum. They occur along tourist paths, mainly

\section{RESULTS AND CONCLUSIONS}

The taxa were classified into four ecological groups: B - snails of partly shaded habitats, $\mathrm{X}$ - xerophile species, $\mathrm{O}$ - open country snails, $\mathrm{M}$ - mesophile species. Ecological spectra of species (MSS) and of specimens (MSI) are presented to illustrate the ecological composition of the fauna (Fig. 1).

The mollusc assemblages are similar among the four sites but differ in their richness. In all, they comprise 18 species represented by the total of more than a thousand specimens (Table 1). The malacofauna from the Forum Romanum, with the derived thanatocoenosis, is the richest and most representative. It is composed of 16 taxa and 693 specimens. Two xerophile species: Cochlicella acuta and Cernuella virgata, are its main components. Xerotricha conspurcata and Microxeromagna vestita, two mesophile snails, are also fairly abundant, while the remaining species are only poorly represented. In the described assemblage the proportion of specimens of xerophile snails is $84 \%$, of mesophile snails - $15 \%$ and of open-country snails $1 \%$ (Fig. 1 - FR-MSI). The quantitative relation between the two species of Cochlicella, examined only in this site, is noteworthy because $C$. acuta is represented by a relatively high number of specimens in contrast within small patches of short vegetation, scattered among the old walls. It is noteworthy that a relatively diverse flora growing between the inner walls of this antique amphitheatre has been known for a few hundred years.

Land snails and their empty shells were additionally collected in another three archaeological and historical complexes, situated outside Rome but not far from the capital. The first included the ruins of the vast antique harbour city Ostia Antica, situated close to the outlet of the Tiber River to the Tyrrhenian See. The fauna found there was relatively rich and diverse. The Hadrian Villa (Villa Adriana) in Tivoli which covers about one square kilometre was the next examined site. The last site - ruins of the Nero Villa - is situated at Antium close to the coast.

Soil with scattered snail shells and shell-rich thanatocoenoses were sampled in each locality. The whole collection from Rome included 28 litter samples, more than a half of them derived from the Forum Romanum. Many snails were also collected by hand. Standard methods of malacological analysis described by LOŽEK (1964) and ALEXANDROWICZ \& ALEXANDROWICZ (2011) were applied. The material was cleaned by washing, dried and sieved to select all live snails, shells and identifiable shell fragments.

The fauna was identified based on publications of GERMAIN (1969), KERNEY et al. (1983), FECHTER \& FALKNER (1990), SCHÜTT (1993) and CossignANI \& COSSIGNANi (1995).

to the similar and related $C$. barbara, represented by few shells.

The snail assemblage from the Palatine Hill is relatively poor. It includes only 10 taxa and 138 specimens and is also composed of two ecological groups: xerophile and mesophile species, constituting $71 \%$ and $29 \%$, respectively (Fig. 1 - Pl-MSI). One species Cernuella virgata - clearly dominates and is accompanied by relatively numerous specimens of Xerotricha conspurcata. The two species of Cochlicella are nearly equally represented. Only one shell of Marmorana muralis was found, but several specimens of this species occurred among the ruins of Ostia Antica.

The malacocoenosis and thanatocoenosis from the Capitol Hill are more diverse, including 14 taxa and 247 specimens. Snails of all four ecological groups are present. This is the only site in which the number of specimens of mesophile species, living in both open and shady habitats, exceeds that of xerophile species $(56 \%$ and $40 \%$, respectively; Fig. 1 Cp-MSI). Xerotricha conspurcata and Cernuella virgata are the main components of this fauna, accompanied by a considerable number of Eobania vermiculata, living in partly shaded places below walls of old build- 
ings. The occurrence of relatively numerous clausiliids, namely Papillifera papillaris, is noteworthy.

The assemblage from the Colosseum is quite poor, composed of only 8 taxa and 84 specimens. They represent two ecological groups: xerophile species (constituting 57\%) and mesophile snails (43\%; Fig. 1 Cl-MSI). Two species, Cernuella virgata and Xerotricha conspurcata, dominate and are represented by a considerable number of specimens.

The faunas from the four described sites and those from the other three mentioned localities represent the same type of mollusc community. It seems to be characteristic of open or slightly shaded, dry habitats, distributed among the ruins and old buildings, visited by numerous tourists and subject to human impact. It is an assemblage composed of two ecological groups of snails (X, M) and dominated by the few species specified above (Fig. 2).

Species of different ecological groups are represented by specimens of somewhat different size and shape. It depends mainly on such habitat features as shadiness or insolation, more or less dense plant cover, dry or humid substratum, as well as of calcium content in the soil. Such local differentiation has been observed mainly in anthropogenic habitats: towns, industrial complexes, historical monuments and tourist centres (ALEXANDROWICZ 1988, 1990, 1995, BARGA-WIECEAWSKA 1997).

Biometrical methods described by REYMENT (1971), ŻUK (1989), ALEXANDROWICZ \&

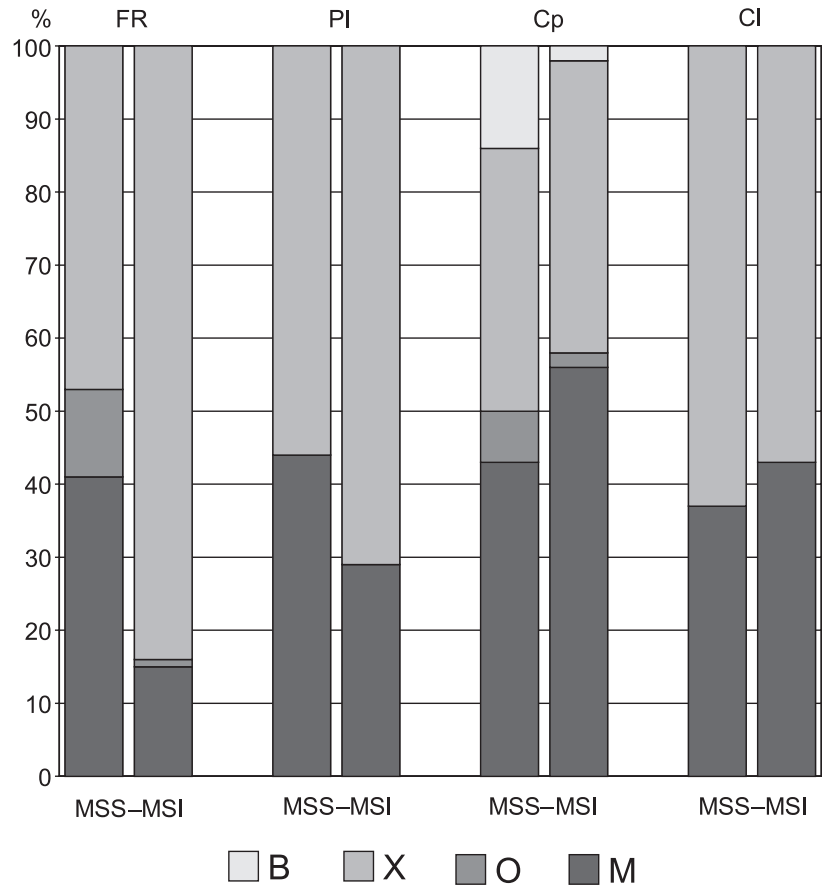

Fig. 1. Malacospectra of species (MSS) and of specimens (MSI) of mollusc assemblages from ancient ruins in Rome. FR - Forum Romanum, Pl - Palatine Hill, Cp Capitol Hill, Cl - Colosseum. Ecological groups of species: $\mathrm{B}$ - snails of partly shaded habitats, $\mathrm{X}$ - xerophile species, $\mathrm{O}$ - open country snails, $\mathrm{M}$ - mesophile species

Table 1. Land snail assemblages from ancient Roman monuments. FR - Forum Romanum, Pl - Palatine Hill, Cp - Capitol Hill, Cl - Colosseum. B, X, O, M - ecological groups of species as in Fig. 1. Number of specimens: I - 1-3, II - 4-9, III 10-31, IV - 32-100, V > 100

\begin{tabular}{|c|c|c|c|c|c|}
\hline $\mathrm{E}$ & S p e c i e s & FR & $\mathrm{Pl}$ & $\mathrm{Cp}$ & $\mathrm{Cl}$ \\
\hline M & Pomatias elegans (O. F. Müller, 1774) & I & II & II & \\
\hline M & Lauria cylindracea (Da Costa, 1778) & I & & & \\
\hline $\mathrm{O}$ & Vallonia costata (O. F. Müller, 1774) & I & & I & \\
\hline $\mathrm{O}$ & Truncatellina cylindrica (Férussac, 1807) & I & & & \\
\hline $\mathrm{X}$ & Papillifera papillaris (O. F. Müller, 1774) & II & II & III & II \\
\hline $\mathrm{X}$ & Rumina decollata (Linnaeus, 1758) & II & I & II & I \\
\hline B & Discus rotundatus (O. F. Müller, 1774) & & & II & \\
\hline M & Oxychilus draparnaudi (Beck, 1837) & I & & II & I \\
\hline $\mathrm{X}$ & Cochlicella acuta (O. F. Müller, 1774) & $\mathrm{V}$ & II & I & \\
\hline $\mathrm{X}$ & Cochlicella barbara (Linnaeus, 1758) & I & II & III & I \\
\hline $\mathrm{X}$ & Cernuella virgata (Da Costa, 1778) & $\mathrm{V}$ & IV & IV & III \\
\hline $\mathrm{X}$ & Caracollina lenticula (Férussac, 1821) & I & & & II \\
\hline M & Microxeromagna vestita (Rambour, 1863) & III & II & III & II \\
\hline M & Xerotricha conspurcata (Draparnaud, 1801) & IV & III & IV & III \\
\hline $\mathrm{O}$ & Monacha cartusiana (O. F. Müller, 1774) & I & & I & \\
\hline M & Eobania vermiculata (O. F. Müller, 1774) & I & I & IV & \\
\hline M & Helix aspersa O. F. Müller, 1774 & I & & I & \\
\hline $\mathrm{X}$ & Marmorana muralis (O. F. Müller, 1774) & & I & & \\
\hline
\end{tabular}




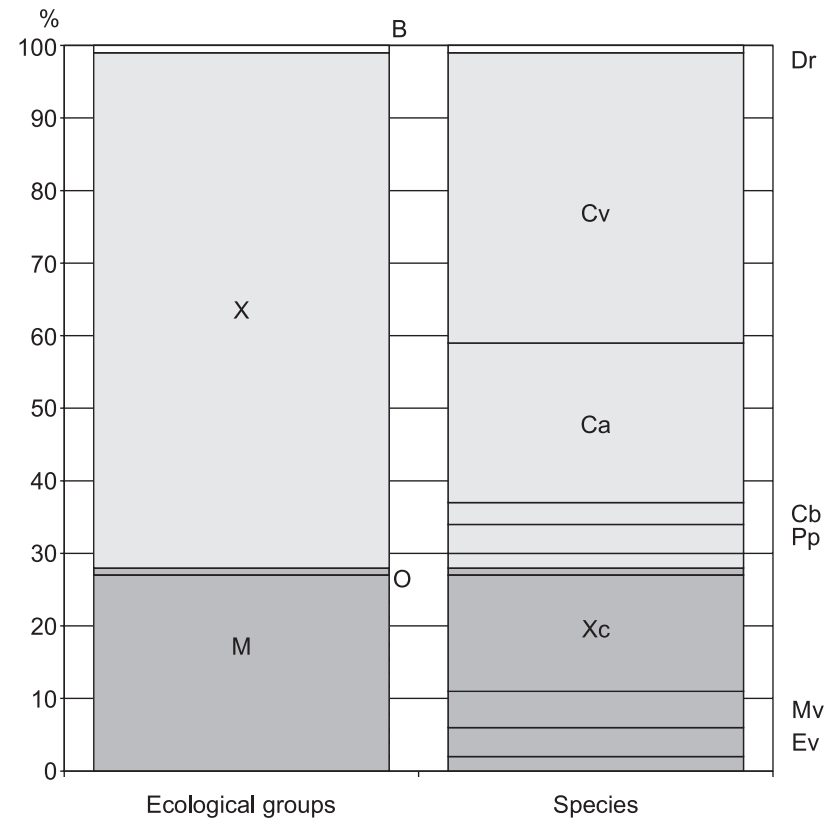

Fig. 2. Comprehensive malacospectrum of species from four ancient Roman monuments. Ecological groups of species as in Fig. 1. Cv - Cernuella virgata, $\mathrm{Ca}$ - Cochlicella acuta, $\mathrm{Cb}$ - Cochlicella barbara, $\mathrm{Dr}$ - Discus rotundatus, $\mathrm{Pp}$ - Papillifera papillaris, Xc - Xerotricha conspurcata, Mv Microxeromagna vestita, Ev - Eobania vermiculata

ALEXANDROWICZ (2011) and other authors were used to characterise populations of selected species. The specimens were measured to determine the shell parameters: height $(\mathrm{H})$ and breadth $(\mathrm{B})$, with the arithmetic mean $(\overline{\mathrm{x}})$, standard deviation $(\mathrm{s})$, standard error $(\mathrm{m})$, variation coefficient $(\mathrm{cv})$, confidence interval $(\overline{\mathrm{x}} \pm 2 \mathrm{~m})$, as well as minimum and maximum dimension (min-max). Additionally the $\mathrm{H} / \mathrm{B}$ ratio was calculated as the shape indicator, to determine its arithmetic mean with the related confidence interval. The number of specimens measured per population (n) was 31-52 (Table 2).
Populations of six species collected within the ancient monuments in Rome were measured and studied using biometrical methods to characterise the shell size and shape. The results are related to dimensions of recently living species as well as compared to general data published by KERNEY et al. (1983), FECHTER \& FALKNER (1990) and COSSIGNANI \& COSSIGNANI (1995), which are limited to the size range and supplemented with illustrations.

- Cochlicella acuta from Forum Romanum - the mean shell dimensions correspond with the lowest values reported by the mentioned authors while $\mathrm{H} / \mathrm{B}$ values are somewhat smaller.

- Cochlicella barbara from Capitol Hill - the compared dimensions are similar.

- Papillifera papillaris from Capitol Hill (also from Colosseum) - the relations are as in the first mentioned species.

- Cernuella virgata from Forum Romanum - the shells are distinctly smaller than those described by the cited authors.

- Xerotricha conspurcata from Forum Romanum (also from Capitol Hill) - the compared dimensions are quite similar.

- Eobania vermiculata from Capitol Hill - the shells are somewhat smaller and flatter in relation to those previously described.

Compared to the land snail fauna found in natural habitats outside towns, the snail assemblages from the ancient Roman monuments are relatively poor and less diverse, composed of few species. This is directly visible from the species lists. Another difference is apparent in the size structure of the populations, mainly in the mean shell dimension and rarely in shell shape. Such differences were only rarely estimated biometrically and statistically before; the described material provides some interesting data. The shell height $(\mathrm{H})$ of three of the measured species defined by arithme-

Table 2. Biometrical features of selected species from ancient monuments in Rome. Explanations in the text

\begin{tabular}{|c|c|c|c|c|c|c|c|c|c|c|c|c|}
\hline \multirow[t]{2}{*}{ Species } & \multicolumn{2}{|c|}{$\begin{array}{l}\text { Cochlicella } \\
\quad \text { acuta }\end{array}$} & \multicolumn{2}{|c|}{$\begin{array}{c}\text { Cochlicella } \\
\text { barbara }\end{array}$} & \multicolumn{2}{|c|}{$\begin{array}{c}\text { Papillifera } \\
\text { papillaris }\end{array}$} & \multicolumn{2}{|c|}{$\begin{array}{l}\text { Cernuella } \\
\text { virgata }\end{array}$} & \multicolumn{2}{|c|}{$\begin{array}{l}\text { Xerotricha } \\
\text { conspurcata }\end{array}$} & \multicolumn{2}{|c|}{$\begin{array}{c}\text { Eobania } \\
\text { vermiculata }\end{array}$} \\
\hline & $\mathrm{H}$ & B & $\mathrm{H}$ & B & $\mathrm{H}$ & B & $\mathrm{H}$ & B & $\mathrm{H}$ & B & $\mathrm{H}$ & B \\
\hline $\mathrm{x}$ & 10.89 & 4.57 & 9.19 & 4.82 & 12.33 & 3.29 & 6.63 & 9.22 & 4.3 & 6.84 & 17.9 & 26.8 \\
\hline $\mathrm{s}$ & 1.079 & 0.344 & 0.943 & 0.421 & 0.855 & 0.152 & 0.628 & 0.74 & 0.372 & 0.372 & 1.692 & 2.564 \\
\hline $\mathrm{m}$ & 0.185 & 0.059 & 0.17 & 0.076 & 0.119 & 0.021 & 0.115 & 0.135 & 0.063 & 0.063 & 0.267 & 0.405 \\
\hline $\mathrm{cV}$ & 9.91 & 7.53 & 10.26 & 8.73 & 6.93 & 4.62 & 9.47 & 1.46 & 8.66 & 5.44 & 9.45 & 9.57 \\
\hline$x-2 m$ & 10.52 & 4.45 & 8.85 & 4.66 & 12.09 & 3.25 & 6.4 & 8.95 & 4.17 & 6.71 & 17.34 & 25.99 \\
\hline$x+2 m$ & 11.26 & 4.7 & 9.53 & 4.96 & 12.57 & 3.33 & 6.86 & 9.49 & 4.43 & 6.96 & 18.44 & 27.61 \\
\hline $\min$ & 9.4 & 3.9 & 7.1 & 4.2 & 10.8 & 3.1 & 5.7 & 7.6 & 3.5 & 6.2 & 13 & 23 \\
\hline \multirow[t]{2}{*}{$\max$} & 14.9 & 5.7 & 11.6 & 5.7 & 13.8 & 3.6 & 7.8 & 10.4 & 5 & 7.5 & 22 & 33 \\
\hline & \multicolumn{2}{|c|}{$\begin{array}{l}\mathrm{H} / \mathrm{B}=2.382 \\
(2.33-2.43)\end{array}$} & \multicolumn{2}{|c|}{$\begin{array}{l}\mathrm{H} / \mathrm{B}=1.906 \\
(1.87-1.94)\end{array}$} & \multicolumn{2}{|c|}{$\begin{array}{l}\mathrm{H} / \mathrm{B}=3.75 \\
(3.69-3.81)\end{array}$} & \multicolumn{2}{|c|}{$\begin{array}{l}\mathrm{H} / \mathrm{B}=0.719 \\
(0.71-0.73)\end{array}$} & \multicolumn{2}{|c|}{$\begin{array}{l}\mathrm{H} / \mathrm{B}=0.628 \\
(0.56-0.70)\end{array}$} & \multicolumn{2}{|c|}{$\begin{array}{l}\mathrm{H} / \mathrm{B}=0.669 \\
(0.65-0.68)\end{array}$} \\
\hline
\end{tabular}


tic mean $(\overline{\mathrm{x}})$ and confidence interval $(\overline{\mathrm{x}} \pm 2 \mathrm{~m})$, presented against the minimum and maximum values of this feature published by KERNEY et al. (1983) (min-max) is as follows: Cochlicella acuta: $\overline{\mathrm{x}}=10.89 \pm 0.37 \mathrm{~mm}$; min- $\max =10-20 \mathrm{~mm}$ (rarely 30 $\mathrm{mm}) ;$ Cochlicella barbara: $\overline{\mathrm{x}}=9.19 \pm 0.34 \mathrm{~mm}$; min-max=8-12 mm; Papillifera papillaris: $\overline{\mathrm{x}}=12.33 \pm$ $0.24 \mathrm{~mm}$; $\min -\max =12-15 \mathrm{~mm}$. The shell breadth (B) values for the other three species are: Cernuella virgata: $\overline{\mathrm{x}}=9.22 \pm 0.27 \mathrm{~mm}$; $\min -\max =8-25 \mathrm{~mm}$; Xerotricha conspurcata: $\overline{\mathrm{x}}=6.84 \pm 0.13 \mathrm{~mm}$; $\min -\max =$ 5-8 mm; Eobania vermiculata: $\overline{\mathrm{x}}=26.80 \pm 0.81 \mathrm{~mm}$; $\min -\max =22-33 \mathrm{~mm}$.

\section{REFERENCES}

AleXANDrowicz S. W. 1988. Malacofauna of the Wawel Hill in Cracow. Folia Malacol. 2: 29-51.

AleXANDrowicz S. W. 1990. Malacofauna of dumps of the soda factory in Cracow. Folia Malacol. 4: 25-37.

AlEXANDROwicz S. W. 1995. Ruins of Carpathian Castles as refuges of land snails. Rocz. Ochr. Przyr. 52: 2-18.

AleXAndrowicz S. W. 2003. Planorbella duryi (Wetherby, 1879) from the Crater-Lake Albano (Central Italy). Folia Malacol. 11: 89-93.

ALEXANDROWICZ S. W. 2004. Shell assemblages on shores of crater lakes near Rome. Folia Malacol. 12: 84-85.

AlexANDROWICZ S. W. 2005. Autochtoniczne i paraautochtoniczne tanatocenozy muszlowe w Lido di Ostia koło Rzymu. Rocznik Polskiej Akademii Umiejętności, rok 2004/2005: 297-303.

AleXANDrowicz S. W., AleXANDrowicz W. P. 2011. Analiza malakologiczna - metody badań i interpretacji. Rozprawy Wydziału Przyrodniczego PAU 3: 1-302.

BARGA-WIĘCŁAWSKA J. 1997. Sukcesja ślimaków na hałdach regionu świętokrzyskiego. Wyższa Szkoła Pedagogiczna, Kielce.

Cossignani T., Cossignani V. 1995. Atlante delle conchiglie terrestri e dulciacquicole italiane. Monstra Mondiale Malacologia, Cupra Marittima.

FECHTER R., FALKNer G. 1990. Weichtiere. Mosaik Verlag, München.

Germain L. 1969. Faune de France, 21, Mollusques terrestres et fluviatiles. Office Central de Faunistique, Nedeln/Lichtenstein.

HALDEMANN R. 1990. Die Gastropodenfauna des Burgberges Rochburg bei Karl-Marx-Stadt, mit Neufund von
The shell size of the specimens of the species from the Roman ruins are within lower intervals of the range of variation given for these species in Europe. This observation is confirmed by COSSIGNANI \& COSSIGNANI's (1995) data from Italy, indicating that populations of the above-mentioned species from natural habitats in the surrounding province Lazio are composed of larger specimens. The results of comparison of land snail populations living in towns and around them, within natural habitats, are similar. Such biometrical studies seem to be useful but are conducted only sporadically.

Helicodiscus singleyanus (Pilsbry) für die Fauna der DDR. Malak. Abh. 15: 73-80.

Kerney M. P., Cameron R. A. D., Jungbluth J. H. 1983. Die Landschnecken Nord- und Mitteleuropas. Verlag Paul Parey, Hamburg und Berlin.

LOŽEK V. 1964. Quartärmollusken der Tschechoslovakei. Rozpravy Ústředního Ústavu Geologického, Praha 31: $1-374$.

MATZKe M. 1985. Synantrope Besiedlungen mit Landschnecken bei Schlössern und Burgen am nördlichen Fusse des Westerzgebierges und Halle (Saale). Malak. Abh. 10: 131-138.

MüNZIG K. 1977. Schnecken an zwei Burgruinen des östlichen Schwarzwaldes. Malak. Abh. 5: 263-266.

REYMENT R. A. 1971. Introduction to Quantitative paleoecology. Elsevier Publ. Comp., Amsterdam-LondonNew York.

SCHÜTT H. 1993. Türkische Landschnecken. Verlag Christa Hemmen, Wiesbaden.

ZeISSLER H. 1968. Die Schnecken and der Burgruine Heoneck bei Nassa. Malak. Abh. 2: 113-117.

ZEISSLER H. 1980. Über die Schnecken an der Burgruine "Maienluft" bei Wassungen, mit einen Ausblick nach dem Muschelkalkgebiet um Meiningen. Malak. Abh. 6: 207-212.

ŻUK B. 1989. Biometria stosowana. PWN, Warszawa.

Received: February 27th, 2012

Revised: May 15th, 2012

Accepted: August 25th, 2012 